\title{
Gambaran kadar glukosa darah puasa pada pekerja kantor
}

\author{
${ }^{1}$ Louis E. Ugahari \\ ${ }^{2}$ Yanti M. Mewo \\ ${ }^{2}$ Stefana H. M. Kaligis
}

\author{
${ }^{1}$ Kandidat Skripsi Fakultas Kedokteran Universitas Sam Ratulangi Manado \\ ${ }^{2}$ Bagian Biokimia Fakultas Kedokteran Universitas Sam Ratulangi Manado \\ Email: louis_esther22@yahoo.com
}

\begin{abstract}
Blood glucose must be maintained in a constant concentration. Hyperglycemia, an increase of blood glucose level, can be a symptom of diabetes mellitus. One of the factors that affect the blood glucose level is physical activity. Low physical activity can be influenced by work. Sedentary lifestyle is identic with office workes. Office workers do not enough time to do physical activity. This study was aimed to describe the fasting blood glucose level among office workers. This was a descriptive study with a cross sectional design. Respondents were obtained by using total sampling method. There were 52 respondents in this study consisted of 25 males and 27 females. The results showed that 45 respondents $(86.54 \%)$ had normal fasting blood glucose levels, 5 respondents $(9.62 \%)$ had high fasting blood glucose levels (hyperglycemia), and 2 respondents (3.84\%) had low fasting blood glucose levels (hypoglycemia). The maximum value was $243 \mathrm{mg} / \mathrm{dL}$, the minimum value was $63 \mathrm{mg} / \mathrm{dL}$, the median value was $83 \mathrm{mg} / \mathrm{dL}$, the average value was $94.42 \mathrm{mg} / \mathrm{dL}$, and standard of deviation was $37.85 \mathrm{mg} / \mathrm{dL}$. Conclusion: Most office workers had normal blood glucose levels.
\end{abstract}

Keywords: fasting blood glucose, office workers

\begin{abstract}
Abstrak: Glukosa darah dalam tubuh manusia harus dijaga dalam konsentrasi yang konstan. Kadar glukosa darah dalam tubuh yang meningkat (hiperglikemia) dapat menjadi gejala penyakit diabetes mellitus. Salah satu faktor yang memengaruhi kadar glukosa darah ialah aktivitas fisik. Aktivitas fisik yang kurang dapat dipengaruhi oleh pekerjaan. Pola hidup sedentary lifestyle identik dengan pekerja kantor dewasa ini. Pekerja kantor tidak memiliki waktu untuk terlibat dalam aktivitas fisik yang cukup. Penelitian ini bertujuan untuk mengetahui gambaran kadar glukosa darah puasa pada pekerja kantor. Jenis penelitian ialah deskriptif dengan desain potong lintang. Pemilihan responden dilakukan dengan metode total sampling. Responden terdiri dari 25 orang laki-laki s dan 27 orang perempuan. Hasil penelitian mendapatkan 45 responden $(86,54 \%)$ memiliki kadar glukosa darah puasa normal, 5 responden $(9,62 \%)$ memilki kadar glukosa darah puasa tinggi (hiperglikemia), dan 2 responden $(3,84 \%)$ memilki kadar glukosa puasa rendah (hipoglikemia). Hasil pengukuran kadar glukosa darah puasa mendapatkan nilai maksimum $243 \mathrm{mg} / \mathrm{dL}$, nilai minimum 63 $\mathrm{mg} / \mathrm{dL}$, nilai median $83 \mathrm{mg} / \mathrm{dL}$, nilai rata-rata $94,42 \mathrm{mg} / \mathrm{dL}$ dan standar devisiasi 37,85 $\mathrm{mg} / \mathrm{dL}$. Simpulan: Sebagian besar pekerja kantor masih memiliki kadar glukosa darah puasa yang normal.
\end{abstract}

Kata kunci: glukosa darah puasa, pekerja kantor

Kadar glukosa darah dalam tubuh yang meningkat (hiperglikemi) dapat menjadi gejala penyakit diabetes mellitus. Diabetes melitus disebabkan insulin tidak dapat bekerja secara normal karena insulin tidak cukup atau tidak efektif. ${ }^{1,2}$ 
Prevalensi diabetes melitus di Sulawesi Utara sebesar 2,4\% menunjukkan Sulawesi Utara sebagai salah satu provinsi dengan angka prevalensi diabetes mellitus yang tertinggi di Indonesia. Laporan Riset Kesehatan Dasar (Riskesdas) pada tahun 2013 menunjukkan prevalensi diabetes mellitus di Indonesia sebesar 6,9\%. ${ }^{3}$

Kadar glukosa darah dapat dipengaruhi berbagai faktor, salah satunya adalah aktivitas fisik. Aktivitas fisik yang kurang dapat dipengaruhi oleh jenis pekerjaan. Penelitian yang dilakukan oleh Nyenwe et al. tahun 2003 mendapatkan 55,8\% orang yang pekerjaanya ringan memiliki kadar glukosa darah tinggi dan menderita diabetes mellitus. ${ }^{4}$

Orang dewasa yang terkena diabetes melitus tipe 2 (DMT2) memiliki gaya hidup kurang aktif. Pekerja kantor cenderung memiliki gaya hidup kurang aktif. Pekerja kantor tidak memiliki waktu untuk terlibat dalam aktivitas fisik yang cukup. ${ }^{5}$ Kesibukan merupakan salah satu masalah yang dihadapi para pekerja kantor. Saat ini, aktivitas fisik di kantor semakin sedikit sehingga para pekerja membakar 140 kalori lebih sedikit bila dibandingkan dengan 50 tahun silam, dan hanya sekitar $6,5 \%$ pekerja yang melakukan aktivitas fisik sambil bekerja. ${ }^{6}$

Penggunaan energi bervariasi tergantung pada jenis aktivitas fisik dan pekerjaan. Pekerja kantor sebagian besar memiliki aktivitas fisik kurang dan tergolong aktivitas fisik intensitas ringan. Penelitian yang dilakukan pada karyawan PT Indocement Citieureup oleh Nurjanah dan Roosita ${ }^{7}$ didapatkan aktivitas fisik yang dilakukan subjek tergolong aktivitas fisik intensitas ringan $(64,4 \%)$.

Gaya hidup yang tidak aktif bergerak diketahui berpotensi memicu beragam gangguan metabolik. ${ }^{7}$. Salah satu indikator terjadi gangguan metabolik ialah terjadi peningkatan kadar glukosa darah dalam tubuh. $^{8}$ Hasil penelitian menunjukkan kecenderungan terjadi peningkatan gangguan metabolik pada pekerja di Indonesia. Penelitian Sumiardji mendapatkan bahwa $24,4 \%$ penyakit di kalangan pekerja terkait dengan gangguan metabolik. ${ }^{9}$ Gangguan metabolik dapat memicu terjadinya penyakit, salah satunya penyakit ialah diabetes melitus. ${ }^{9}$

Aktivitas fisik kurang menjadi penyebab utama diabetes melitus sebesar $27 \% .^{10}$ Aktivitas fisik yang kurang memengaruhi peningkatan kadar gula darah. Melakukan aktivitas fisik dapat mengendalikan kadar glukosa darah karena pada saat beraktivitas fisik diperlukan energi yang diubah dari glukosa. ${ }^{11}$. Menurut Riskesdas tahun 2007, secara nasional hampir separuh penduduk $(48,2 \%)$ termasuk dalam aktivitas fisik yang kurang dan sebesar 47,2\% kurangnya aktivitas fisik terdapat di Sulawesi Utara. ${ }^{10}$

Penelitian ini bertujuan untuk mengetahui gambaran kadar glukosa darah puasa pada pekerja kantor.

\section{METODE PENELITIAN}

Jenis penelitian ini ialah survei deskriptif dengan desain potong lintang. Responden berjumlah 52 orang dengan pemilihan responden berdasarkan metode total sampling, yaitu memilih responden yang memenuhi kriteria tertentu: pekerja tata usaha perkantoran PT.Bank SULUTGO dengan lama kerja $\geq 8$ jam dan bersedia menjadi responden.

Pengambilan responden dilakukan dengan menggunakan kuesioner untuk mendapatkan responden yang sesuai dengan kriteria, setelah itu responden diminta untuk mengisi dan menandatangani informed consent. Penilaian kadar glukosa darah puasa (GDP) dilakukan dengan pengambilan darah pada vena mediana cubiti setelah responden berpuasa selama 10-12 jam. Dalam penelitian ini penilaian kadar GDP menggunakan nilai rujukan menurut laboratorium klinik Patra.

\section{HASIL PENELITIAN}

Berdasarkan pengumpulan data pada responden, ditemukan jumlah responden laki-laki hampir sama banyak dengan jumlah responden perempuan (Tabel 1).

Berdasarkan kadar glukosa darah puasa yang nilai normal merujuk pada nilai 
normal laboratorium klinik Patra yaitu 70$125 \mathrm{mg} / \mathrm{dL}$, didapatkan sebagian besar responden memiliki kadar glukosa darah puasa dalam batas normal $(86,54 \%)$ (Tabel 2).

Tabel 1. Distribusi responden berdasarkan jenis kelamin

\begin{tabular}{ccc}
\hline $\begin{array}{c}\text { Jenis } \\
\text { Kelamin }\end{array}$ & (n) & $(\boldsymbol{\%})$ \\
\hline Laki-laki & 25 & 48,08 \\
Perempuan & 27 & 51,92 \\
Jumlah & 52 & 100 \\
\hline
\end{tabular}

Hasil pengukuran kadar glukosa darah puasa didapatkan nilai maksimum 243 $\mathrm{mg} / \mathrm{dL}$, nilai minimum $63 \mathrm{mg} / \mathrm{dL}$, nilai median $83 \mathrm{mg} / \mathrm{dL}$, nilai rata-rata 94,42 $\mathrm{mg} / \mathrm{dL}$ dan standar devisiasi $37,85 \mathrm{mg} / \mathrm{dL}$.

Tabel 2. Distribusi responden berdasarkan kadar glukosa darah puasa

\begin{tabular}{crc}
\hline Interpretasi & & \\
Hasil & $(\mathrm{n})$ & \multicolumn{1}{c}{$(\%)$} \\
\hline Rendah & 2 & 3,84 \\
Normal & 45 & 86,54 \\
Tinggi & 5 & 9,62 \\
Jumlah & 52 & 100 \\
\hline
\end{tabular}

\section{BAHASAN}

Berdasarkan hasil penelitian kadar glukosa darah puasa pada pekerja kantor dengan aktivitas fisik yang kurang didapatkan sebagian besar $(86,54 \%)$ mempunyai kadar glukosa darah puasa normal. Hal ini menjelaskan bahwa kadar glukosa darah puasa tidak hanya bergantung pada aktivitas fisik. Padahal, aktivitas fisik yang kurang menyebabkan kurangnya pembakaran energi oleh tubuh sehingga kelebihan energi dalam tubuh akan disimpan dalam bentuk lemak dalam tubuh dan menyebabkan jumlah timbunan lemak dalam tubuh tidak berkurang serta terjadi peningkatan glukosa dalam darah. ${ }^{12}$

Kadar glukosa darah dalam tubuh manusia selain dipengaruhi oleh aktivitas fisik dapat juga di pengaruhi berbagai macam faktor antara lain: hormon- hormon yang mengatur kadar glukosa darah, umur, stress, dan pola makan. ${ }^{7,13}$ Kadar glukosa darah puasa normal yang didapatkan pada sebagian besar responden kemungkinan disebabkan berbagai faktor, antara lain: umur responden berada di bawah 40 tahun dan adanya hormon-hormon yang berperan dalam pengaturan glukosa darah dalam tubuh manusia. Pada penelitian yang dilakukan Lestari $^{14}$ tahun 2013 hampir seluruh responden $(93,55 \%)$ berusia muda memiliki kadar glukosa darah normal. Responden berusia muda mempengaruhi kadar glukosa darah karena pada usia muda metabolisme karbohidrat dan fungsi organ baik.

Manusia memiliki sistem pengaturan kadar glukosa darah yang melibatkan hati, jaringan-jaringan ekstrahepatik dan hormon-hormon. Saat konsentrasi glukosa darah meningkat, hormon insulin akan disekresi untuk mengurangi konsentrasi glukosa darah ke kadar normal. Saat konsentrasi glukosa darah menurun, glukagon akan disekresi sehingga kadar glukosa darah meeningkat menjadi normal. $^{15,16}$

Pada hasil penelitian, didapatkan juga responden dengan kadar glukosa darah puasa tinggi (hiperglikemia) berjumlah 5 orang. Pada responden yang memiliki kadar glukosa darah puasa tinggi (hiperglikemia) didapati responden yang menderita diabetes melitus sebanyak 2 orang $(9,62 \%)$; hal ini tidak sejalan dengan persentasi jumlah responden yang hiperglikemia pada beberapa penelitian yang telah dilakukan. Pada penelitian yang dilakukan oleh Widiantini dan Tafal ${ }^{17}$ tahun 2014 ditemukan sebagian besar pekerja dengan kategori aktivitas rendah memliki kadar glukosa darah yang tinggi. ${ }^{17}$ Penelitian oleh Zahtamal ${ }^{18}$ tahun 2009 ditemukan hampir sebagian besar responden yang berkerja dengan aktivitas terbatas memiliki kadar glukosa darah tidak terkontrol. Penelitian lainnya oleh Amir ${ }^{19}$ tahun 2015 yang dilakukan pada 22 responden penelitian ditemukan sebagian responden (9 reponden atau 40,9\%) yang tidak melakukan aktivitas fisik, tidak berolahraga memiliki kadar glukosa darah yang tinggi. ${ }^{19}$ 
Pada penelitian yang dilakukan oleh Widiantini dan Tafal ${ }^{17}$ ditemukan bahwa responden dengan usia 30-49 tahun berisiko 2,3 kali lebih besar untuk mengalami obesitas dan kadar glukosa darah meningkat dibandingkan dengan usia kurang dari 30 tahun. Responden dengan usia 50-64 tahun berisiko 2,5 kali lebih besar untuk mengalami obesitas dan memiliki kadar glukosa darah meningkat dibandingkan dengan usia kurang dari 30 tahun. Penelitian oleh Zahtamal ${ }^{18}$ mendapatkan hubungan bermakna antara usia dan kejadian kadar glukosa darah tinggi dan diabetes melitus. Pada penelitian ini, ditemukan $88,61 \%$ kasus kejadian pada usia $>45$ tahun. ${ }^{18}$ Penelitian lainnya yang dilakukan oleh Amir ${ }^{19}$ menunjukkan bahwa 8 dari 11 respondon yang termasuk pada kelompok usia 40-60 tahun memiliki kadar glukosa darah yang tinggi.

Pertambahan usia memengaruhi kadar glukosa darah seseorang. Pada hasil penelitian yang dilakukan ditemukan responden yang mengalami hiperglikemia cenderung lebih banyak berada di umur 4160 tahun dibandingkan dengan responden yang berumur di bawah 40 tahun. Hal ini menunjukkan hasil yang sejalan dengan penelitian yang dilakukan oleh Sumangkut $^{20}$ tahun 2013 pada 43 responden penelitian yang mendapatkan sebanyak 24 orang responden berada di usia 41-60 tahun dengan kadar glukosa darah tinggi dan penderita diabetes mellitus. ${ }^{20}$ Teori mengatakan dengan semakin bertambah usia, kemampuan jaringan mengambil glukosa darah semakin menurun. ${ }^{12,20}$

Seseorang yang menderita diabetes melitus, nilai kadar GDP tinggi (hiperglikemia). Pada DMT1, terjadi kekurangan insulin karena pankreas tidak menghasilkan sama sekali insulin atau menghasilkan insulin tetapi tidak cukup. Pada DMT1 terdapat kelainan sel $\beta$ pankreas yang menyebabkan sel $\beta$ pankreas gagal berespon terhadap stimulasi yang semestinya meningkatkan sekresi insulin. Pada DMT2 terjadi kekurangan insulin karena insulin yang dihailkan pankreas dalam jumlah normal tidak bekerja secara efektiff atau terjadi resistensi insulin. ${ }^{1,2}$

Peningkatan kadar glukosa darah puasa pada pekerja kantor selain dapat disebabkan oleh aktivitas fisik yang kurang dan usia yang bertambah tua dapat juga disebabkan pola makan setiap individu. Pola makan berupa perilaku makan yang tidak sehat, asupan serat yang kurang, konsumsi makanan manis berlebihan, dan tidak membatasi konsumsi pangan menyebabkan kadar glukosa dalam darah terganggu. ${ }^{7,13}$

Berdasarkan hasil penelitian kadar GDP pada pekerja kantor, didapatkan juga kadar GDP rendah (hipoglikemia) berjumlah 2 orang (3,84\%). GDP yang rendah (hipoglikemia) menurut Sabatine tahun 2003 dapat disebabkan keterlambatan asupan glukosa, aktivitas fisik berlebihan, gagal ginjal, konsumsi alkohol, paska melahirkan, dan penggunaan obat-obatan dalam jumlah besar seperti salisilat, dan sulphonamide. ${ }^{21,22}$ Dalam hal ini penurunan kadar glukosa darah pada responden kemungkinan dapat disebabkan keterlambatan asupan glukosa. Berkurangnya asupan karbohidrat atau glukosa pada responden karena responden menjalani puasa dalam jangka waktu yang lama (>12 jam), sehingga terjadinya hipoglikemia karena berkurangnya asupan glukosa dari saluran cerna. $^{22}$ Dalam keadaan puasa, kadar insulin menurun sehingga menurunkan ambilan glukosa oleh hepar, otot dan lemak. Glukogenolisis didalam hati merupakan proses paling peenting untuk memenuhi kebutuhan glukosa dalam keadaan puasa selama 12-24 jam. ${ }^{22}$

Keterbatasan penelitian ini ialah kurangnya informasi mengenai pola makan untuk mengetahui asupan glukosa pada responden. Selain itu, pada penelitian ini tidak dapat dikontrol dengan ketat lamanya waktu puasa sehingga ada responden yang berpuasa melebihi batas waktu yaitu 12 jam.

\section{SIMPULAN}

Dari hasil penelitian dapat disimpulkan bahwa sebagian besar pekerja kantor 
memiliki kadar glukosa darah puasa normal.

\section{SARAN}

Disarankan agar responden yang memiliki kadar glukosa darah puasa normal tetap mempertahankan kadar glukosa darahnya. Bagi responden yang memilki kadar glukosa darah yang meningkat atau menurun sebaiknya memenuhi asupan glukosa sesuai kebutuhan dan memeriksakan kadar glukosa secara rutin. Bagi responden yang kadar glukosa darah $>200 \mathrm{mg} / \mathrm{dL}$ agar dapat berkonsultasi ke dokter dan melakukan pemeriksaan lanjut untuk mendapatkan penatalaksanaan.

Pada penelitian lanjut disarankan menggunakan responden dengan jumlah yang lebih banyak, jenis pekerjaan yang lebih bervariasi, ataupun dilakukan penelitian analitik dengan menganalisis dua atau lebih variabel.

\section{UCAPAN TERIMA KASIH}

Ucapan terima kasih disampaikan kepada PT.Bank SULUTGO yang telah mengijinkan peneliti melakukan penelitian, para responden yang telah bersedia, laboratorium klinik Patra yang telah membantu pemeriksaan laboratorium pada penelitian ini, dan pada semua pihak yang baik secara langsung maupun tidak langsung telah menumbuhkan ide atau gagasan dalam pemikiran penulis sehingga dapat menyelesaikan tulisan ini.

\section{DAFTAR PUSTAKA}

1. Baradero M. Gangguan endrokin seri asuhan keperawatan. Jakarta: ECG, 2005.

2. Syamiyah N. Faktor risiko kejadian diabetes mellitus tipe 2 pada wanita di puskesmas kecamatan Pesanggraha Jakarta Selatan tahun 2014 [Skripsi]. Jakarta: Program Studi Kesehatan Masyarakat Universitas Islam Negeri Syarif Hidayatullah; 2014.

3. Hasil Riset Kesehatan Dasar (Riskesdas). Badan Penelitian dan Pengembangan Kesehatan. Kementerian Kesehatan RI, 2013. Available from: www.depkes.go.id/resources/downloa $\mathrm{d} /$ general/Hasil\%20Riskesdas\%20201 3.pdf. Cited: September $9^{\text {th }} 2016$

4. Wahyuni S. Faktor-faktor yang berhubungan dengan penyakit diabetes mellitus daerah perkotaan di Indonesia tahun 2007 [Skripsi]. Jakarta: Program Studi Kesehatan Masyarakat Universitas Islam Negeri Syarif Hidayatullah; 2010.

5. Zahtamal, Rochmah W, Prabandari YS, Setyawati LK. Prevalensi sindrom metabolik pada pekerja perusahaan. Jurnal Kesehatahan Masyarakat Nasional. 2014;9(2):113-20.

6. Church TS, Thomas DM, Tudor-Locke C, Katzmarzyk PT, Earnest CP, Rodarte RQ, et al. Trends over \% decades in U.S occupation-related physical activity and their associations with obesity. PLos ONE. 2011;6(5):e19657, doi:10.1371/journal.pone.0019657

7. Nurjanah F, Roosita K. Gaya hidup dan kejadian sindrom metabolik pada karyawan laki-laki berstatus gizi obes di PT. Indocement Citieureup. J Gizi Pangan. 2015;10(1):17-24.

8. Bender AB, Mayes PA. Karbohidrat yang penting secara fisiologis. In: Murray RK, Granner DK, Rodwell VW, editors. Biokimia Harper (27th ed). Pendit BU, alih bahasa Indonesia. Wulandari $\mathrm{N}$, editor edisi bahasa Indonesia. Jakarta: ECG, 2009; p. 119-27.

9. Zahtamal, Rochmah W, Prabandari YS, Setyawati LK. Prevalensi sindrom metabolik pada pekerja perusahaan. Jurnal Kesehatahan Masyarakat Nasional. 2014;9(2):113-20.

10. Hasil Riset Kesehatan Dasar (Riskesdes). Badan Penelitian dan Pengembangan Kesehatan, Kementerian Kesehatan RI, 2007.

11. Nggilu R. Hubungan indeks massa tubuh dengan kadar gula darah sewaktu penderita diabetes mellitus tipe 2 di wilayah kerja puskesmas Global kecamatan Limboto kabupaten Gorontalo [Skripsi]. Gorontalo: Fakultas Ilmu Kesehatan dan Keolahragaan, Universitas Negeri Gorontalo; 2015. 
12. Suiraoka, IP. Penyakit degenerative. Yogyakarta: Nuha Medika;2012. p.45-51.

13. Bitanah S, Handarsari E. Asupan serat dengan kadar gula darah, kadar kolesterol total dan status gizi pada pasien diabetes mellitus tipe 2 di rumah sakit Roemani Semarang. Seminar Hasil-hasil Penelitian LPPM UNIMUS. 2012;289-96

14. Lestari D. Gambaran kadar glukosa darah puasa pada mahasiswa fakultas kedokteran Universitas Sam Ratulangi angkatan 2011 dengan indeks massa tubuh $18,5-22,9 \mathrm{~kg} / \mathrm{m}^{2}$ [SKRIPSI]. Program Studi Pendidikan Dokter Universitas Sam Ratulangi, Manado.2013

15. Guyton AC, Hall JE. Buku ajar fisiologi kedokteran. Edisi ke 27. Rachman YL, Hartanto H, Novrianti A, Wulandari, editor edisi bahasa Indonesia. Jakarta: ECG, 2007. p.882-91, 1010-27

16. Bender AB, Bender AB, Mayes PA. Glikolisis dan oksidasi piruvat. In: Murray RK, Granner DK, Rodwell VW, editors. Biokimia Harper. Edisi ke 27. Pendit BU, alih bahasa Indonesia. Wulandari $\mathrm{N}$, editor edisi bahasa Indonesia. Jakarta: penerbit buku kedokteran ECG;2009. p.1589,162
17. Widiantini W, Tafal Z. Aktivitas fisik, stres dan obesitas pada pegawai negeri sipil. Jurnal Kesehatan Masyarakat Nasional. 2014;8(7):3306

18. Zahtamal. Faktor-faktor risiko pasien diabetes mellitus. Available from: http://berita-kedokteranmasyarakat.org/index.php/BKM/articl e/view/117/42. Accesed on: November $7^{\text {th }} 2016$

19. Amir S, Wungouw H, Pangemanan D. Kadar glukosa darah sewaktu pada pasien diabetes mellitus tipe 2 di puskesmas Bahu kota Manado. Jurnal eBiomedik, Vol 3, No.1, 2015;32-40

20. Sumangkut S, Supit W, Onibala F. Hubungan pola makan dengan kejadian penyakit diabetes mellitus tipe 2 di poli interna BLU RSUP Prof.dr. R.D. Kandou Manado. Jurnal Keperawatan Universitas Sam Ratulangi.2013;1:2

21. Sabatine Marc S. Buku saku klinis. Jakarta: Hipokrates,2003

22. Budidharmaja E. Faktor-faktor yang mempengaruhi kejadian hipoglikemia pada diabetes mellitus di poliklinik RSUP DR Kariadi [SKRIPSI]. Fakultas Kedokteran, Universitas Diponegoro, Semarang.2013 